\title{
SEISMIC BEHAVIOR OF BIAXIAL HOLLOW REINFORCED CONCRETE SLAB TO CONCRETE-FILLED STEEL TUBULAR COLUMN CONNECTIONS
}

\author{
Chao Gong ${ }^{1}$, Zhao-Xin Hou ${ }^{1}$, Guo-Zhong Cheng ${ }^{2,}$,, Y. Frank Chen ${ }^{2}$ and Wei-Qiao Liang ${ }^{1}$ \\ ${ }^{1}$ Central Research Institute of Building and Construction Co., Ltd, Beijing 100088, China \\ ${ }^{2}$ Key Laboratory of New Technology for Construction of Cities in Mountain Area (Chongqing University), Ministry of Education, Chongqing 400045, China \\ *(Corresponding author: E-mail: chengguozhong@cqu.edu.cn)
}

\section{A B S T RA C T}

This paper discusses the seismic behavior of biaxial hollow reinforced concrete (RC) slab to concrete-filled steel tubular (CFST) column connections. Seven scaled specimens were tested under cyclic loading, where the axial compressive load applied on CFST column was selected as the parameter. Both exterior and interior joints were investigated. Two types of failure modes, i.e., beam failure and column failure, were observed. For specimens with beam failure, the failures are mainly caused by the fracture of top steel beam flange. For specimens with column failure, the failures are primarily triggered by the buckling of tube wall. The proposed composite slim floor system inherently meets the principle of strong joint-weak member. The ultimate story drift of all specimens is 2.2-2.8 times of plastic drift ratio specified in codes, and the equivalent damping coefficient at peak loads ranges from 0.12 to 0.19 , indicating the proposed composite slim floor system has a good seismic performance.
A R T I CLE H IST TORY

$\begin{array}{ll}\text { Received: } & 7 \text { November } 2019 \\ \text { Revised: } & \text { 18 May } 2020 \\ \text { Accepted: } & \text { 30 May } 2020\end{array}$

\section{K E Y W O R D S}

Hollow core slab;

Concrete filled steel tube (CFST);

Connection;

Seismic behavior;

\section{Introduction}

The earliest form of composite slim floor construction was used in the 1790s. Since the introduction in Scandinavia, the composite slim floor system (Fig. 1) has been widely used in Europe and the United States [1, 2]. As shown, a singly symmetrical I-beam with the wider bottom flange supporting a deep deck is used. The key feature is that the steel beam is encased in the slab, resulting in a flat appearance and a decreased beam depth. The steel beam is usually connected to the column through a shear plate and bolts (Fig. 1c), as indicated by the existed literature [3, 4]. The reinforced concrete (RC) slab prevents the steel beam from local buckling and eliminates the need of fire protection $[5,6]$. Therefore, the composite slim floor system is an innovative and alternative floor system to traditional RC floor system and traditional steel-concrete composite floor system. However, the thickness of composite slim floor is larger than that of traditional floor system, which increases the weight of floor system.

Extensive research has been conducted on this type of floor systems, particularly the integrated composite beam and the connection between composite slim floor and column. Nine simply-supported composite slim beams have been tested at Helsinki University of Technology, followed by the parametric studies on the flexural behavior of the beams [7], which indicated that interface slippage in composite slim beams with reinforced bars was much less and could be neglected. Additionally, a study on the behavior of the beam-to-column connections was performed at the same place [8], where a semi-comtinuous beam-column connection was investigated and classified as partial-strength. Experiments on eight specimens were carried out at Trento University to investigate the influences of reinforcement ratios and load conditions on the behavior of composite slim beams [9], which show that the reinforcement ratio has a significant influence on the loading capacity of the composite slim beams. The shear transfer mechanism provided by the shear connectors between steel beam and concrete slab has been also studied, which indicates that interface slippage in composite slim beams is negligible [10,11]. Besides the structural behavior, research has also been done on the fire resistance of composite slim floor systems and it shows that such systems have a good fire resistance $[10,11]$.

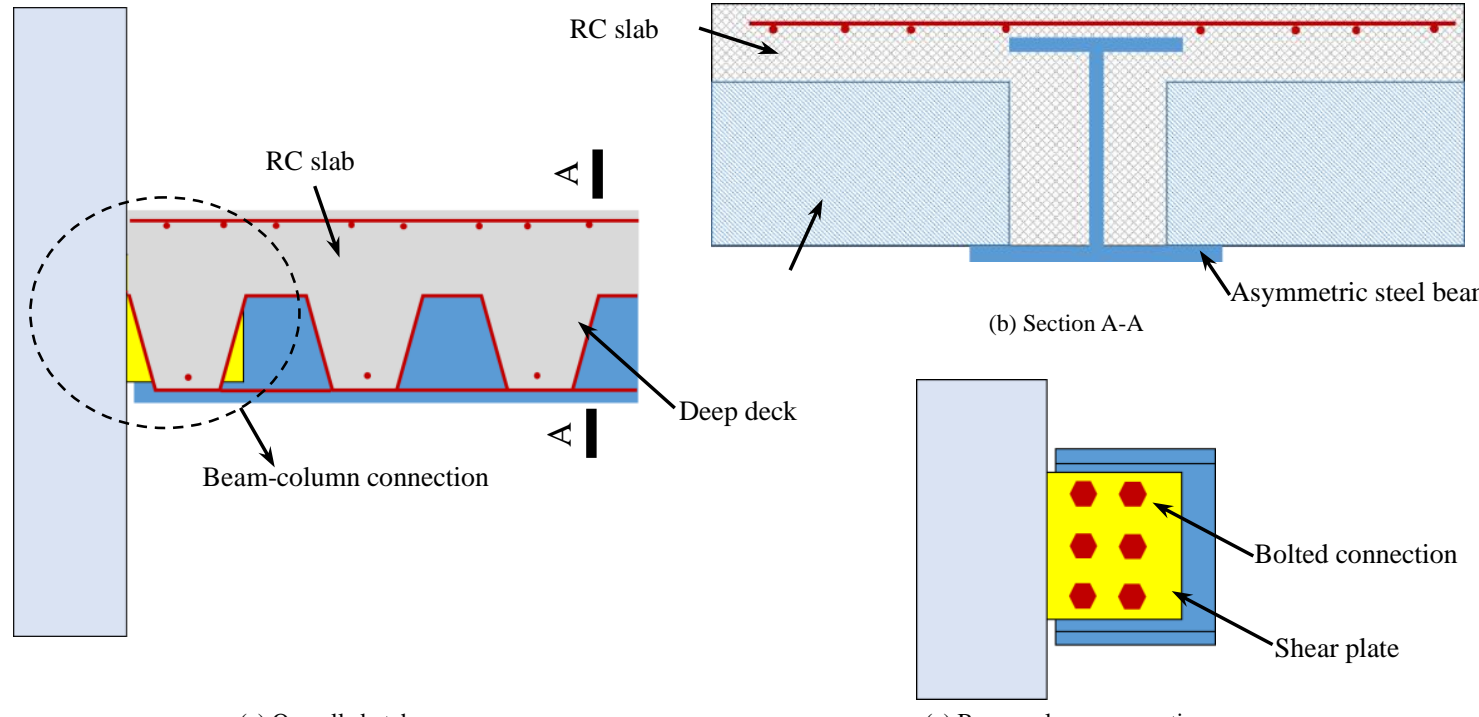

(a) Overall sketch

(c) Beam-column connection

Fig. 1 The composite slim floor system 


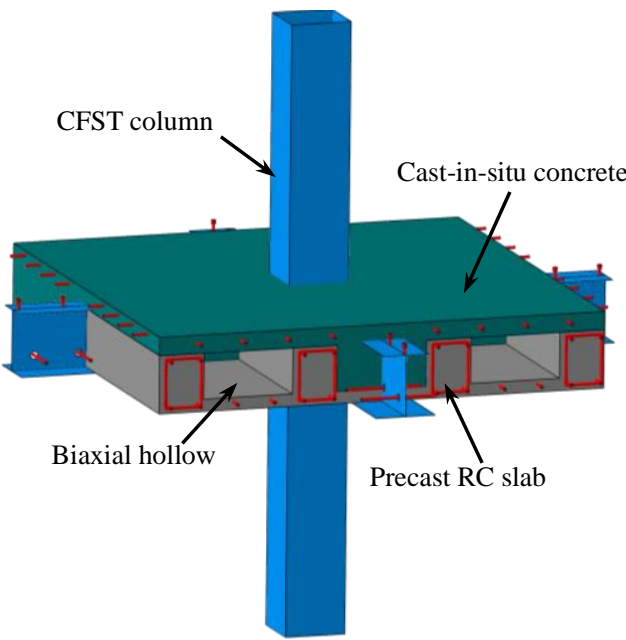

(a) Sketch

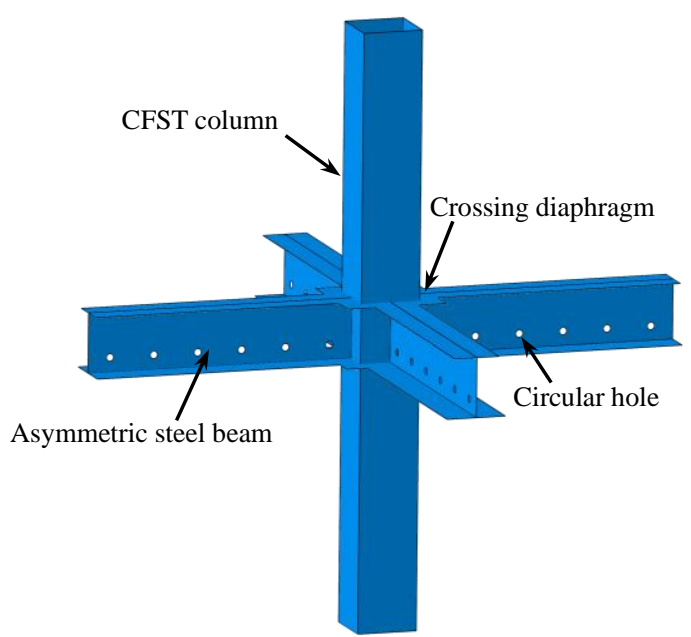

(b) Beam-column connection

Fig. 2 Proposed composite slim floor system

Deep decks or precast concrete (PC) slabs have been commonly used in the conventional composite slim floor system (Fig. 1). However, the design of PC slabs is usually governed by the width of concrete cracks and may be uneconomical. The deep decks, the depth of which is higher than $200 \mathrm{~mm}$, are not available in every place including China. Besides, the deep decks need to be protected from corrosion, which would increase the cost. Moreover, the traditional composite slim floor system is not suitable for moment resistance because of the semi-comtinuous beam-column connections. Therefore, the conventional composite slim floor system is not widely adopted in China. For these reasons, an improved composite slim floor system (Fig. 2) with the rigid beam-column connection is proposed. In this system, an asymmetric steel beam contained in the RC slab is used to minimize the floor depth similarly to the traditional composite slim floor system. The precast RC slabs are employed as the structural components as well as the permanent formwork. Biaxial hollow boxes are introduced to reduce the RC slab weight. The asymmetric steel beam is connected to the concrete filled steel tubular (CFST) column using the crossing diaphragms. As first attempt to study the seismic performance of the proposed floor system, this paper focuses on the seismic behavior of beam-column connection. Seven connection specimens were tested under cyclic loading. The influences of different testing parameters on the seismic behavior of connections were evaluated in detail.

\section{Experimental program}

\subsection{General information of specimens}

Seven connection specimens were tested under cyclic loading, where the details are shown in Fig. 3. As indicated, CFST columns are $200 \mathrm{~mm} \times 200$ $\mathrm{mm}$ in cross-section, $3200 \mathrm{~mm}$ long, and with $6 \mathrm{~mm}$ thick steel tube. The composite slim beam has the cross-section of $800 \mathrm{~mm}$ (width) $\times 270 \mathrm{~mm}$ (height) and the length of $2380 \mathrm{~mm}$ (Fig. 4). It consists of a singly-symmetrical steel I-beam, precast concrete, filler, cast-in-place (CIP) concrete, and rebars. The steel beam has a $36 \mathrm{~mm}$-diameter hole, with both perfobond shear connectors and shear studs adopted to transfer the shear force between RC slab and steel beam. The $14 \mathrm{~mm}$-diameter overlapped rebars pass through the circular hole and the shear studs having the diameter of $10 \mathrm{~mm}$ and the length of $40 \mathrm{~mm}$ were welded to the beam flange. Both the overlapped rebars and the shear studs were spaced evenly at $200 \mathrm{~mm}$. The beam flanges were made continuous with the crossing diaphragms, thus eliminating the uncertain effect caused by flange welds (Fig. 3(c)). The crossing diaphragms was designed according to Chinese code CECS 159: 2004 [12]. The average compressive strength of concrete is $35.4 \mathrm{MPa}$ for the RC slab and $38.6 \mathrm{MPa}$ for the CFST column, which were measured from six concrete cubes $(150 \mathrm{~mm}$ $\times 150 \mathrm{~mm} \times 150 \mathrm{~mm})$. To assess the effect of connection location, both exterior and interior joints (Fig. 5) were considered. The main parameter investigated is the axial compressive load applied on the CFST column. Additionally, the steel beam to CFST column joint was tested for comparison. Detailed steel material properties are listed in Table 1, and specimen details are listed in Table 2 where $n$ is the axial load ratio of CFST column defined as

$n=N /\left(f_{\mathrm{cc}} A_{\mathrm{c}}+f_{\mathrm{y}} A_{\mathrm{s}}\right)$

in which $N, f_{\mathrm{c}}, f_{\mathrm{y}}, A_{\mathrm{c}}$, and $A_{\mathrm{s}}$ are the axial compressive load applied on CFST column, the axial compressive strength of infilled concrete, the yield strength of steel tube, the cross-sectional area of infilled concrete, and the cross-sectional area of steel tube. 


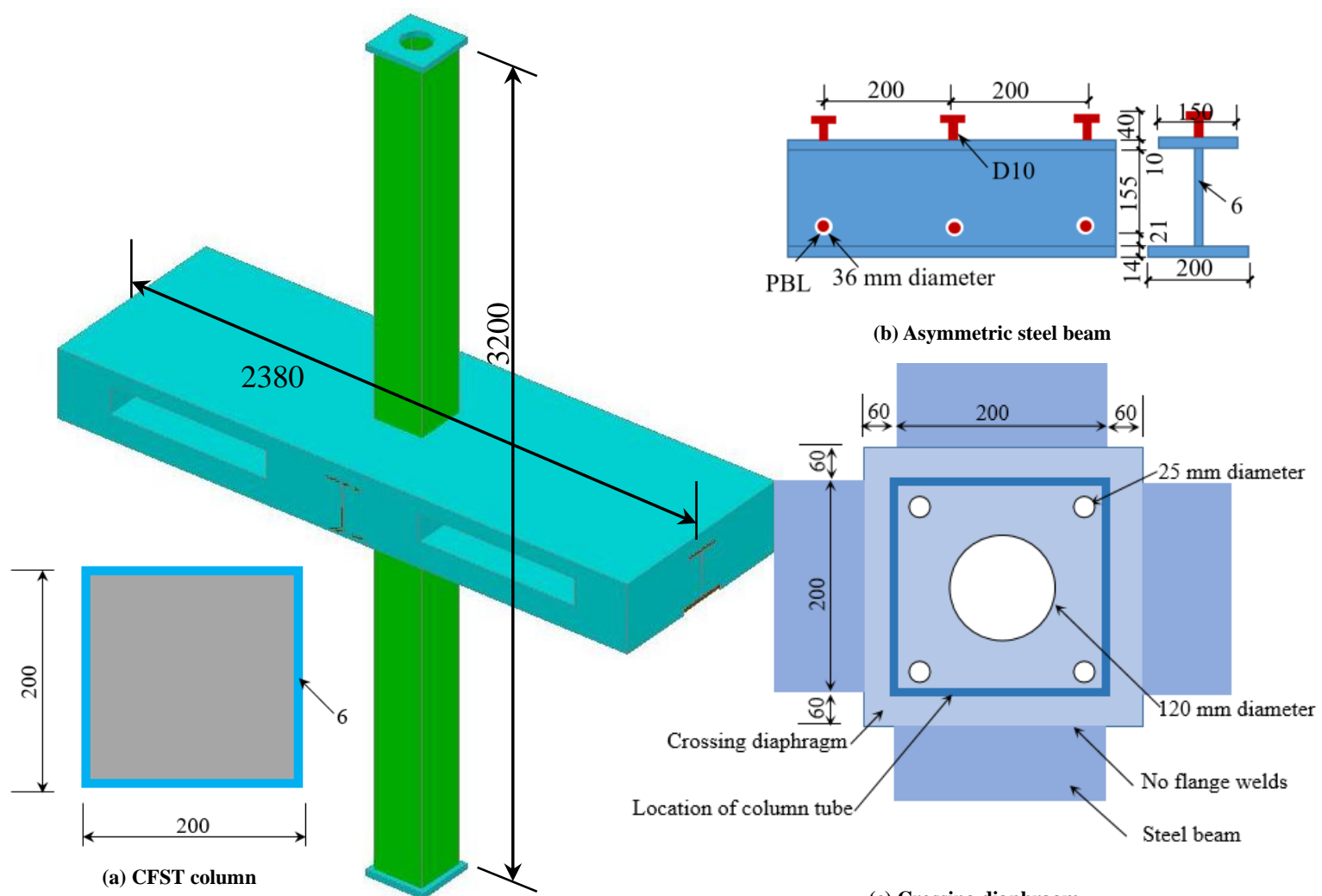

(c) Crossing diaphragm

Fig. 3 Details of specimen (unit: $\mathrm{mm}$ )

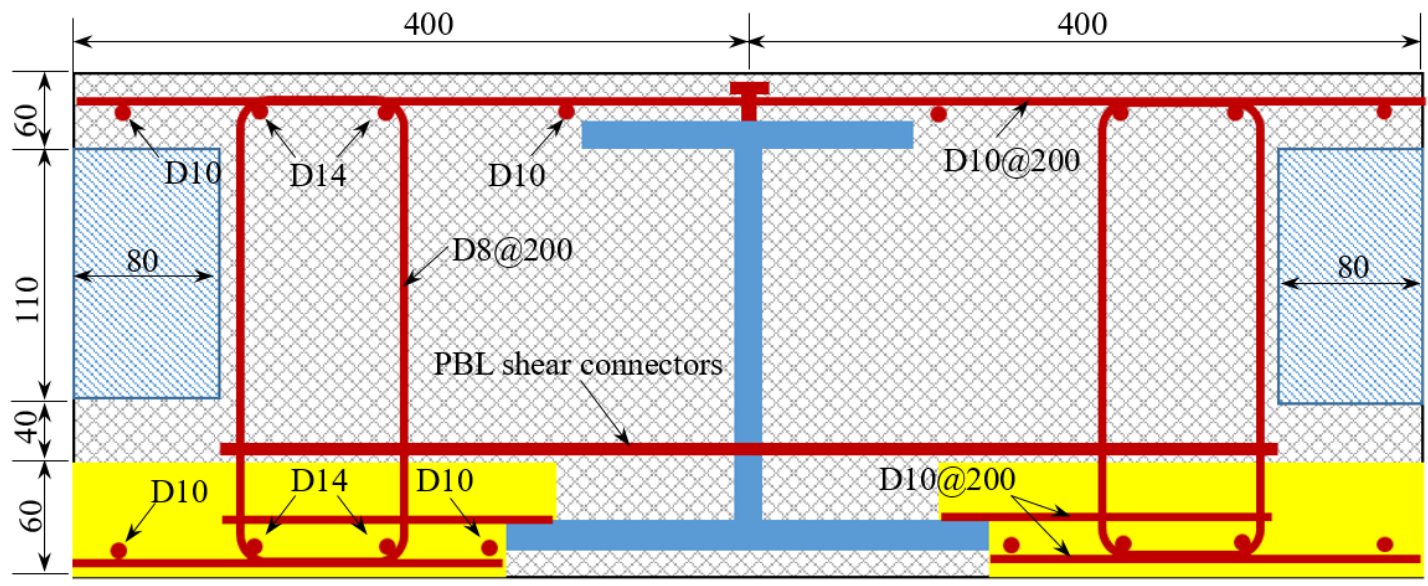

Fig. 4 Cross-section of RC slab

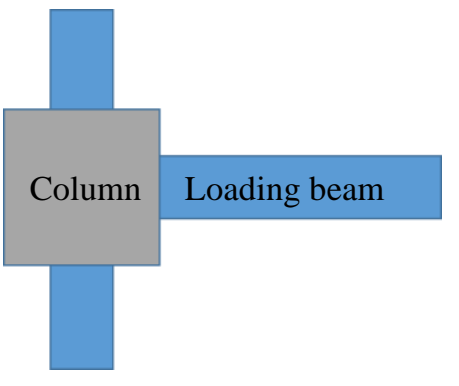

(b) Exterior joints

$$
\underset{\text { Loading direction }}{\longrightarrow}+
$$$$
\text { Loading beam Column Loading beam }
$$ 
Table 1

Material properties of steel

\begin{tabular}{ccc}
\hline Material label & Yield strength $f_{\mathrm{y}}(\mathrm{MPa})$ & Ultimate strength $f_{\mathrm{u}}(\mathrm{MPa})$ \\
\hline $10 \mathrm{~mm}$ deformed steel bar & 433 & 630 \\
$14 \mathrm{~mm}$ deformed steel bar & 436 & 620 \\
$6 \mathrm{~mm}$ thick steel plate & 382 & 508 \\
$8 \mathrm{~mm}$ thick steel plate & 356 & 388 \\
$10 \mathrm{~mm}$ thick steel plate & 367 & 513 \\
$14 \mathrm{~mm}$ thick steel plate & 510 \\
\hline
\end{tabular}

Table 2

Details of specimens (unit: $\mathrm{mm}$ )

\begin{tabular}{|c|c|c|c|c|c|}
\hline Specimen label & CFST column & Asymmetric steel beam & Connection location & $n$ & RC slab \\
\hline Specimen-1 & \multirow{7}{*}{$\begin{array}{l}\text { Width: } 200 \\
\text { Height: } 200 \\
\text { Thickness: } 6\end{array}$} & \multirow{7}{*}{$\begin{array}{l}\text { Height: } 200 \\
\text { Width: } \\
\text { 1. Top flange: } 150 \\
\text { Bottom flange: } 200 \\
\text { Thickness: } \\
\text { 1. Top flange: } 10 \\
\text { 2. Bottom flange: } 14 \\
\text { 3. Web: } 6\end{array}$} & Exterior joints & 0.5 & Without \\
\hline Specimen-2 & & & Exterior joints & 0.2 & With \\
\hline Specimen-3 & & & Exterior joints & 0.5 & With \\
\hline Specimen-4 & & & Exterior joints & 0.6 & With \\
\hline Specimen-5 & & & Interior joints & 0.2 & With \\
\hline Specimen-6 & & & Interior joints & 0.35 & With \\
\hline Specimen-7 & & & Interior joints & 0.5 & With \\
\hline
\end{tabular}

\subsection{Test set-up and instrumentation layout}

All columns and beams were pin-connected at their ends. The inflection points are likely to occur at the column mid-height and beam mid-span during a seismic event, which may be represented by pins. Details of the test set-up and instrumentation layout are shown in Fig. 6. The specimen was loaded by two $1000 \mathrm{kN}$ hydraulic actuators located vertically at the two opposite ends of composite slim beam, while the axial compressive load was applied at the top of column by a $6000 \mathrm{kN}$ hydraulic actuator. According to the JGJ/T 101-2015 [13], the cyclic loading history consists of both force-controlled and displacement-controlled steps.

A load cell and a displacement transducer (LVDT-1) were used to monitor the applied vertical load $(P)$ and displacement $(U)$ at each end of composite slim beam. Strains in the steel beam flanges, crossing diaphragms, and rebars were monitored through strain gauges.

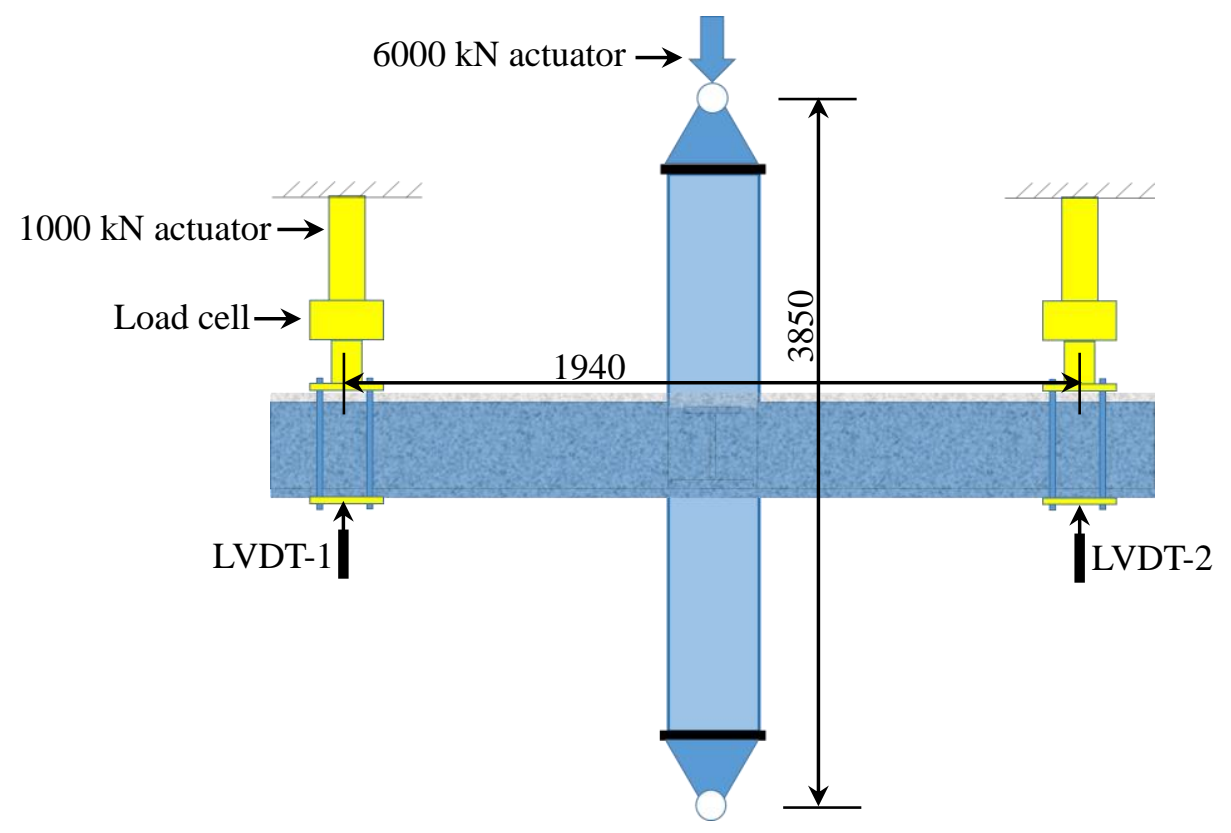

Fig. 6 Test set-up

\section{Failure progression}

(1) Specimen 1

Fig. 7 shows the $P-U$ curves and failure mode of Specimen 1 which has no RC slab. The top steel beam flange began to fracture near the crossing diaphragm with $U=-32 \mathrm{~mm}$ (Fig. 7b), as induced by the stress concentration. The buckling of top steel beam flange was observed at $U=40 \mathrm{~mm}$ (Fig. 7c). At $U=-48 \mathrm{~mm}$, the top steel beam flange completely fractured, followed by the fracture of web (Fig. 7d). 

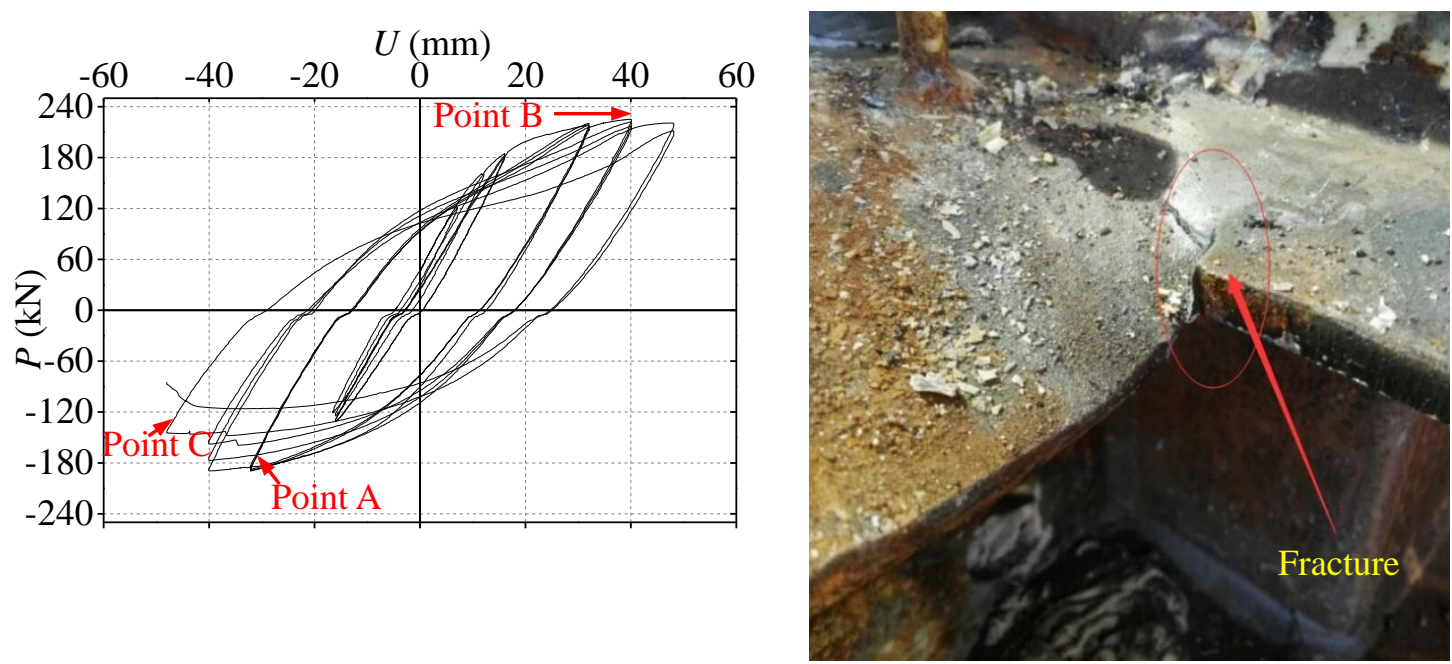

(a) $P$ - $U$ curve

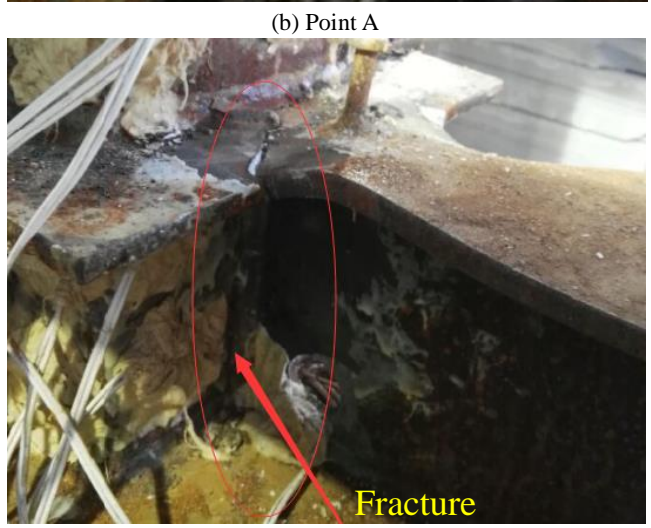

(c) Point B

(d) Point C

Fig. 7 Specimen 1

(2) Specimen 2-4

Since Specimens 2-4 show similar failure modes, Specimen 2 is selected for detailed discussion. The $P-U$ curves and failure modes of Specimen 2 are illustrated in Fig. 8. The bonding failure of rebars occurred first at $U=-30 \mathrm{~mm}$

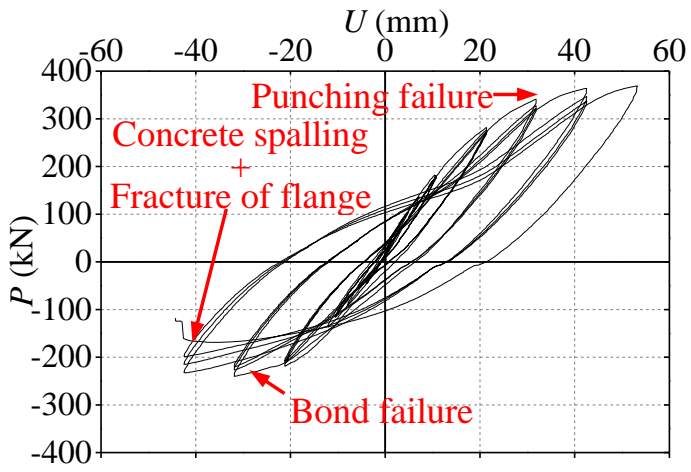

(a) P-U curve

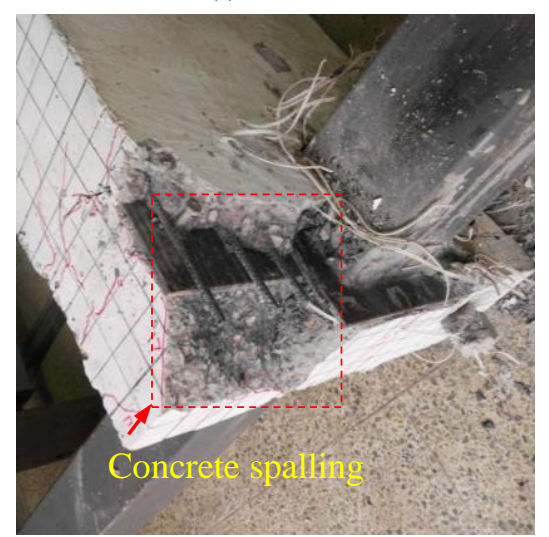

(c) Concrete spalling and the punching failure of concrete was observed at $U=30 \mathrm{~mm}$ (Fig. 8b). At $U=-43 \mathrm{~mm}$, the concrete spalled off (Fig. 8c) and the top steel beam flange eventually fractured completely (Fig. 8d). Similar $P-U$ curves for Specimens 3 and 4 are presented in Fig. 9.

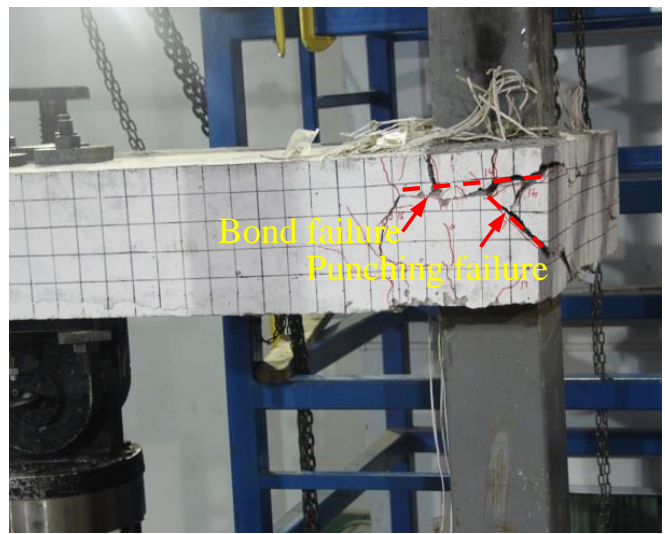

(b) Bonding and punching failures

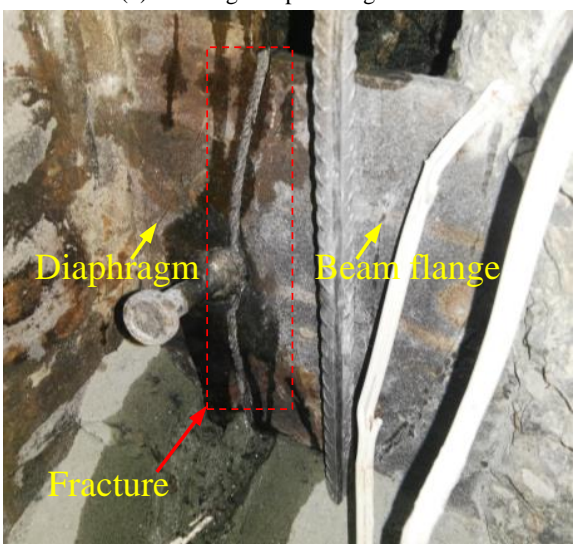

(d) Fracture of flange 


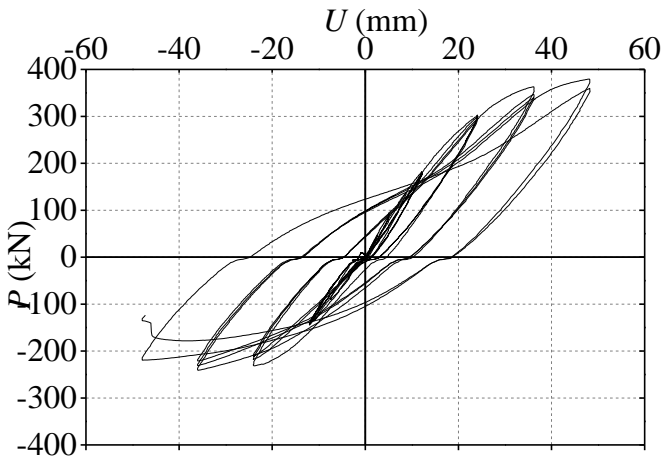

(a) Specimen 3

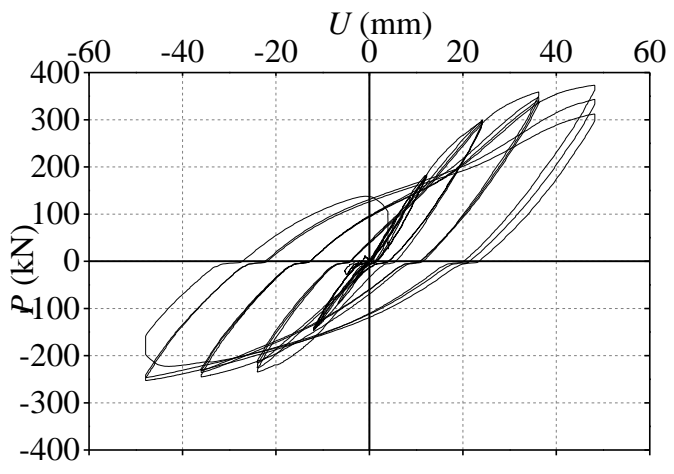

(b) Specimen 4

Fig. $9 P-U$ curves for Specimens 3 and 4

(3) Specimen 5-7

For Specimens 5-7, similar column failure was observed. Specimen 5 is chosen for discussion here. Visible parallel transverse cracks developed first on the top of RC slab adjacent to the column at $U=-9.7 \mathrm{~mm}$ and the cracking region extended with increasing cyclic loads (Fig. 10c). The width of cracks remained small consistently. The wall of steel tube buckled below the diaphragm at $U=57.8 \mathrm{~mm}$ (Fig. 10b). The $P-U$ curves for Specimens 6 and 7 are shown in Fig. 11, which reveal that the tube wall buckles at a smaller $U$ with the higher axial compressive load applied on the column.

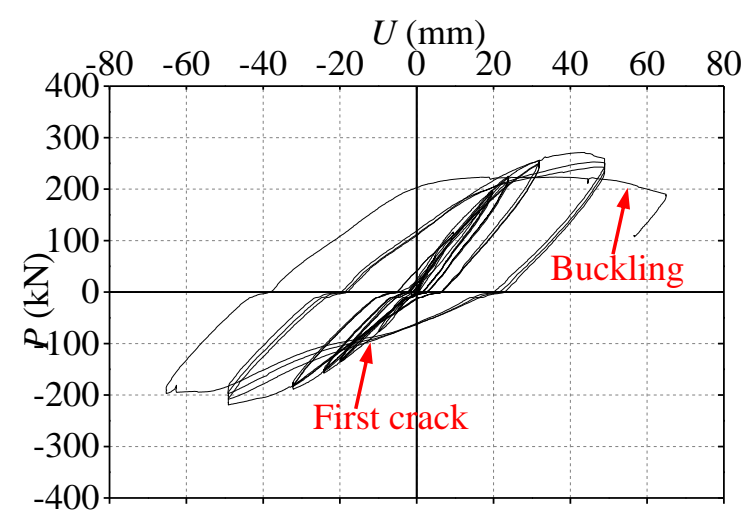

(a) P-U curve

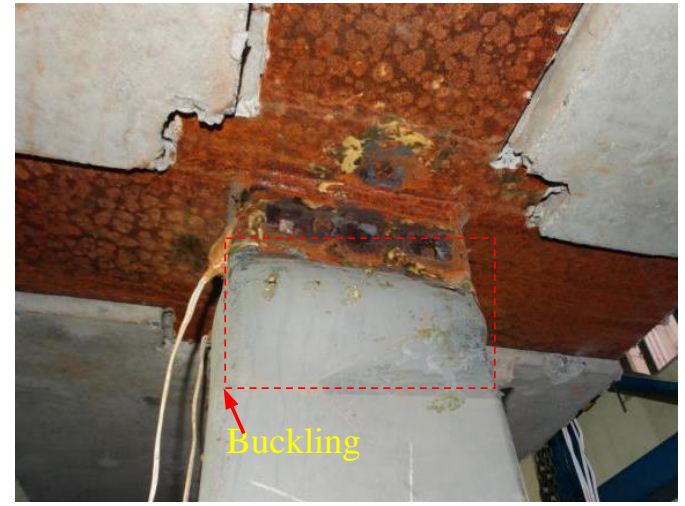

(b) Buckling of steel tube

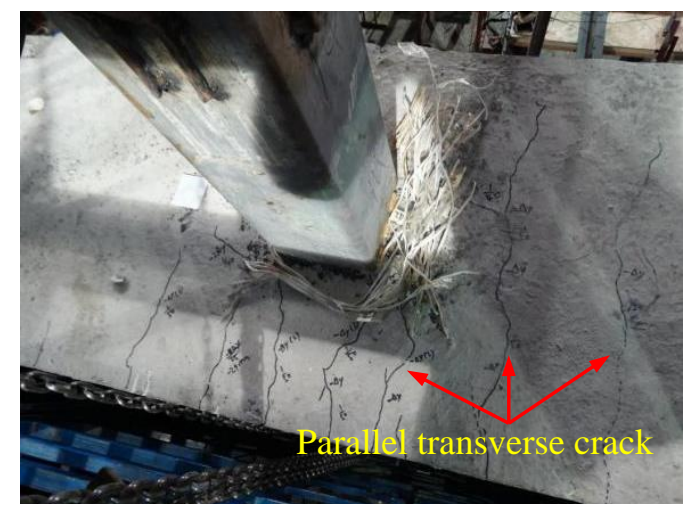

(c) Parallel transverse cracks on the RC slab

Fig. 10 Specimen 5 


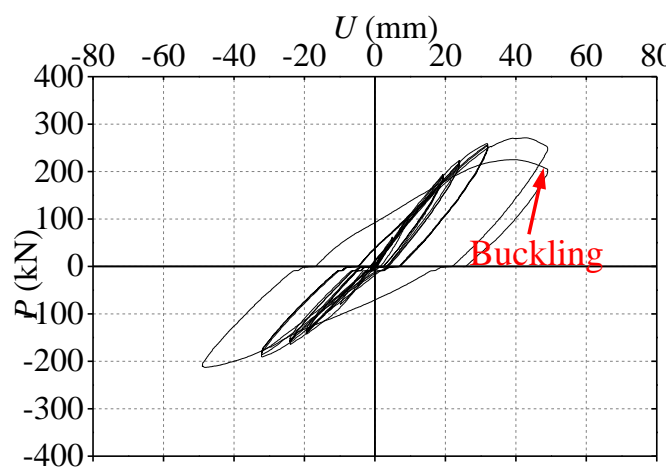

(a) Specimen 6

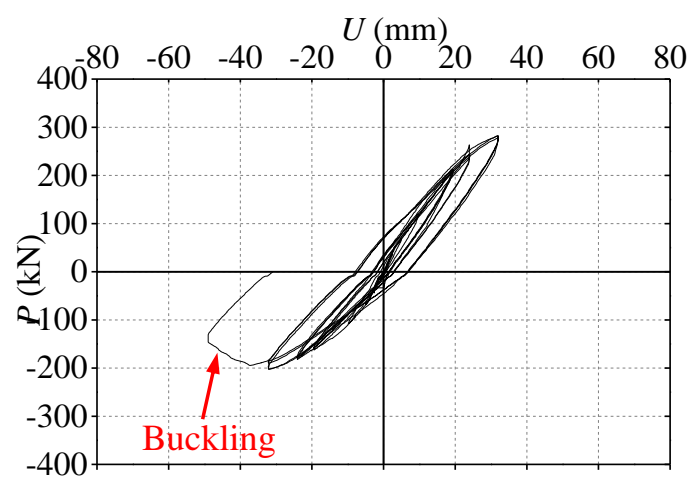

(b) Specimen 7

Fig. $11 P-U$ curves for Specimens 6 and 7

In summary, the failures of Specimens 1-4 are mainly caused by the fracture of top steel beam flange, while the failures of Specimens 5-7 are primarily triggered by the buckling of tube wall. In all tested specimens, the joint zone remains in good shape consistently, which demonstrates that the proposed composite slim floor system inherently meets the principle of strong joint-weak member

\section{Analysis and discussion}

(a) $P-U$ envelope curves

All the $P-U$ envelope curves are highly unsymmetrical, owing to the asymmetric steel beam. Fig. 12 shows the effect of the RC slab on $P-U$ envelope curves. The RC slab embeds the rebars contribute to the beam bending capacity directly and prevents the beam flange from buckling. Under negative loading, the ultimate strength of the specimens with RC slab is $27 \%$ higher than those without RC slab. Under positive loading, the increase is $46 \%$. The results show that the RC slab can significantly increase the bending capacity of a composite slim beam. This fact should be realized in practical rational designs.

Fig. 13 shows the effect of applied axial compressive loads on CFST column on $P-U$ envelope curves. For Specimens 2-4 with beam failure, the axial compressive load has little effect on $P-U$ envelope curves. However, the higher axial compressive load may decrease the deformability of the specimen with column failure.

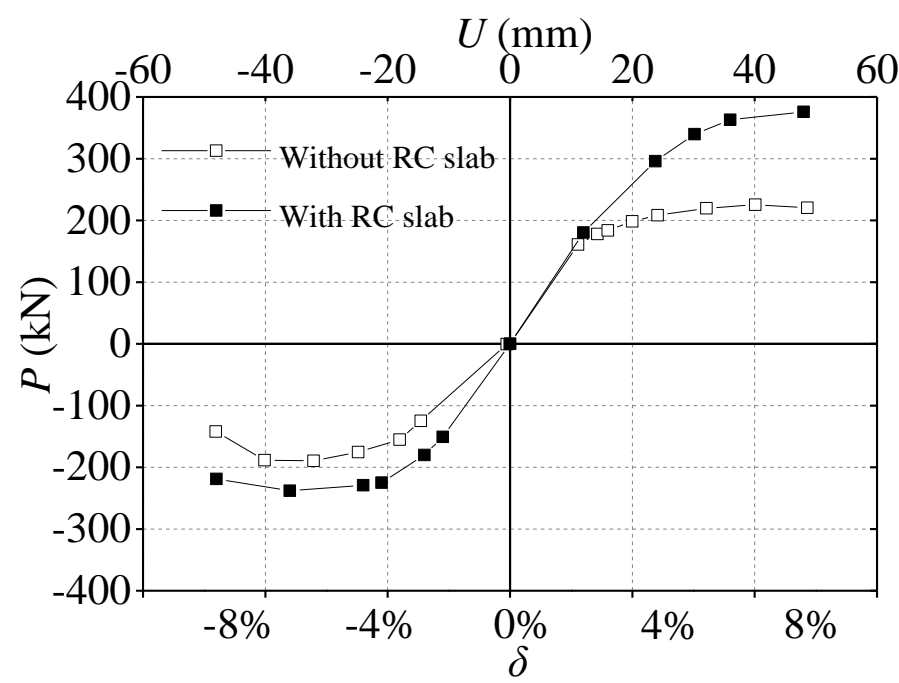

Fig. 12 Effect of RC slab

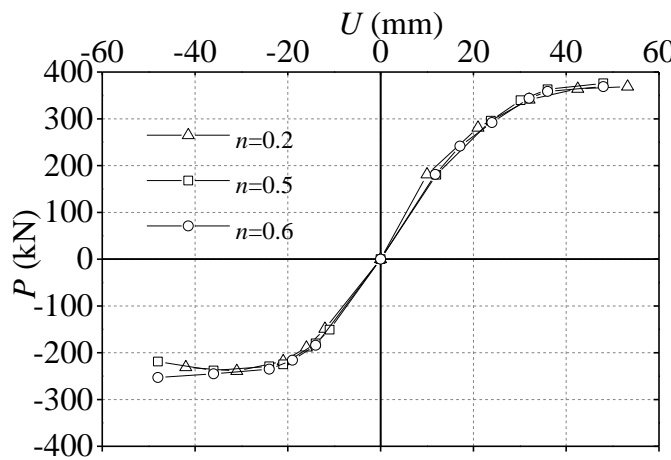

(a) Beam failure

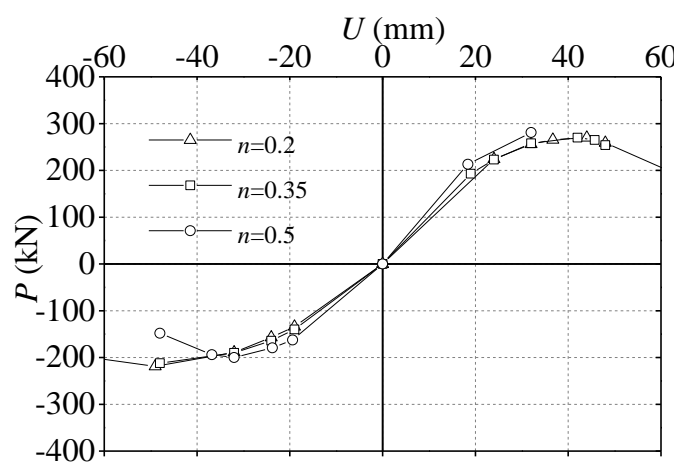

(b) column failure

Fig. 13 Effect of axial compressive loads applied on CFST column

(b) Strains

The readings of the strain gages set on rebars are illustrated in Fig. 14. At exterior joints, the strains of rebars decrease rapidly after $U$ reaches about 24 $\mathrm{mm}$, demonstrating a bond failure of rebars. However, at interior joints the strains of rebars keep increasing before the peak load, indicating the good bond condition of rebars. In practice, a good anchorage should be suggested for the rebars at exterior joints to achieve the fully connection between RC slab and steel beam.

Typical readings of the strain gages set on the steel beam flange and column tube are indicated in Fig. 15. For Specimen 2 with beam failure, the strains of top beam flange exceed the yield strain of steel. By contrary, the strains of column tube are consistently within the yield strain of steel. For Specimen 5 with column failure, the strains of top beam flange do not exceed the yield strain of steel. However, there is a rapid decrease in the strains of column tube, as evidenced by the observed buckling of column tube. 


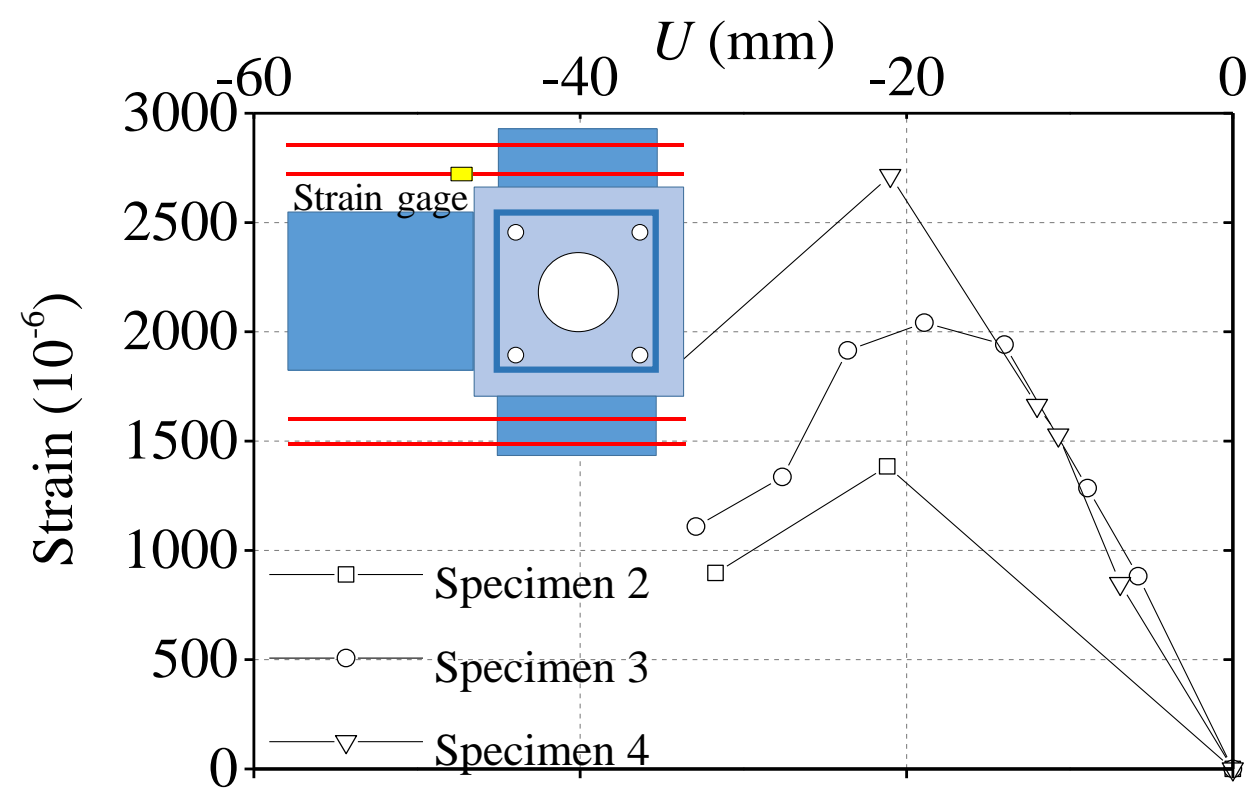

(a) Exterior joints

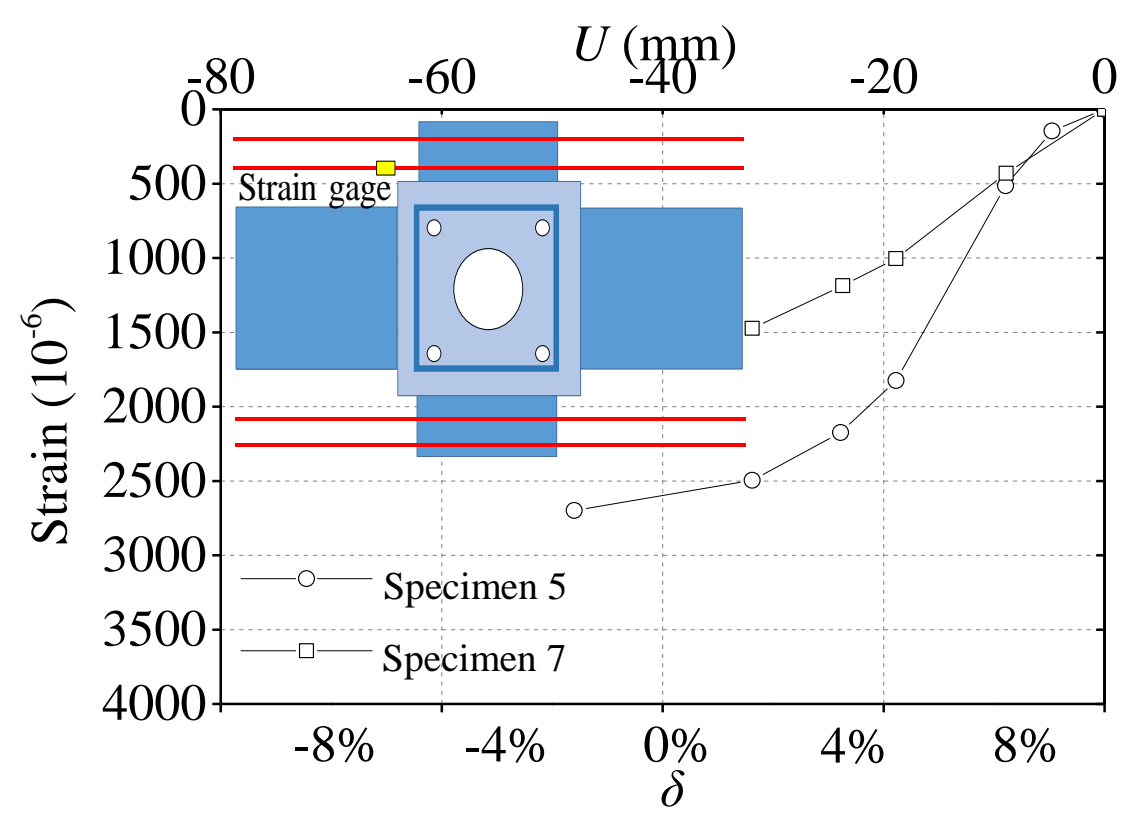

(b) interior joints

Fig. 14 Readings of the strain gages set on rebars

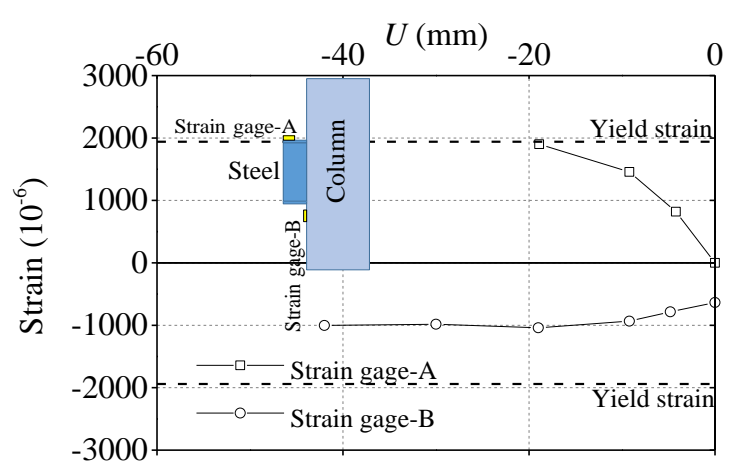

(a) Specimen 2 with beam failure

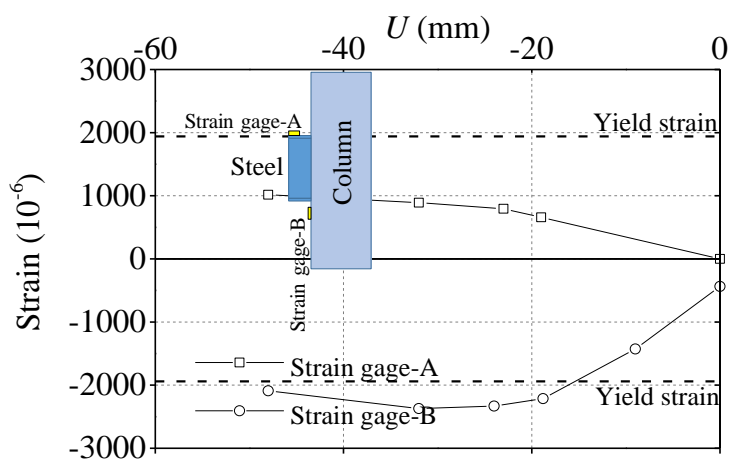

(b) Specimen 5 with column failure

Fig. 15 Readings of the strain gages set on the steel beam flange and column tube 
[14]. The $\mu$ values are listed in Table 3. As seen, the specimens with beam failure have a larger ductility factor, generally exceeding 1.89 . For the specimens with column failure, the $\mu$ value is generally less than 1.81 and decreases with increasing axial compressive loads applied on the CFST column.

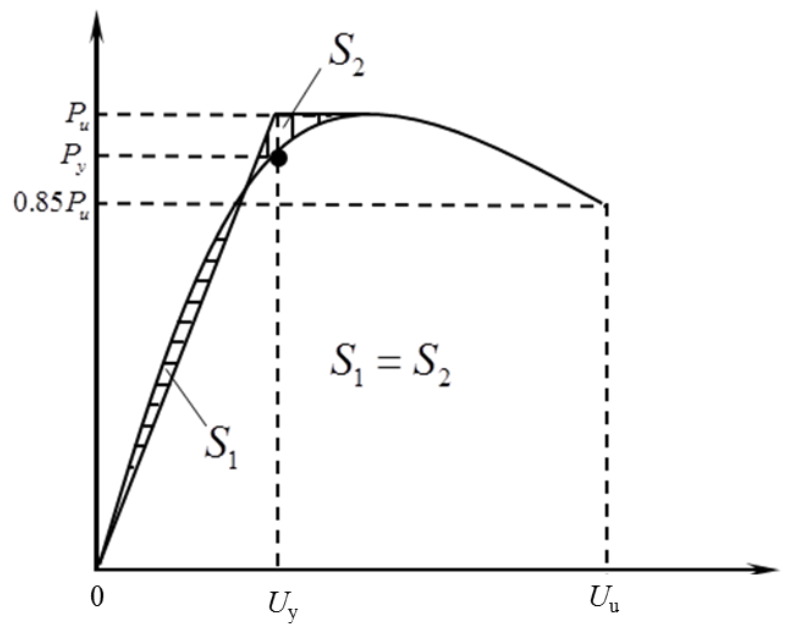

Fig. 16 Method for determining $U_{\mathrm{y}}$ and $U_{\mathrm{u}}$

The story drift $\theta$ is defined as $U /(L / 2)$ where $L$ is the length between composite beam pins, which can be used to evaluate deformation capacity of a specimen. The plastic drift ratio specified in the ASCE/SEI 7-10 [15] and GB $50011-2010[16]$ is $2.0 \%$. The ultimate story drift $\theta_{\mathrm{u}}$, defined as $U_{\mathrm{u}} /(L / 2)$, ranges from 0.044 to 0.056 , which is 2.2-2.8 times of $\theta_{\mathrm{p}}$. Thus, all the specimens satisfy the design code requirements and exhibit good deformation capacity.

Table 3

Test results of all the specimens

\begin{tabular}{|c|c|c|c|c|c|c|c|}
\hline Specimen & Specimen-1 & Specimen-2 & Specimen-3 & Specimen-4 & Specimen-5 & Specimen-6 & Specimen-7 \\
\hline Failure direction & + & + & + & + & + & + & + \\
\hline$P_{\mathrm{y}}(\mathrm{kN})$ & 172 & 218 & 216 & 229 & 249 & 244 & 182 \\
\hline$U_{\mathrm{y}}(\mathrm{mm})$ & 23.9 & 21.2 & 19.6 & 22.6 & 30.3 & 28.9 & 25 \\
\hline$P_{\mathrm{u}}(\mathrm{kN})$ & 160.65 & 1 & I & I & 230 & 1 & 170 \\
\hline$U_{\mathrm{u}}(\mathrm{mm})$ & 44.9 & $>42$ & $>48$ & $>48$ & 54.7 & $>48$ & 42.6 \\
\hline$\mu$ & 1.89 & $>1.98$ & $>2.45$ & $>2.45$ & 1.81 & $>1.66$ & 1.70 \\
\hline$\theta_{\mathrm{u}}$ & 0.046 & $>0.043$ & $>0.049$ & $>0.049$ & 0.056 & $>0.049$ & 0.044 \\
\hline$\theta_{\mathrm{p}}$ & & & & 0.02 & & & \\
\hline$\theta_{\mathrm{u}} / \theta_{\mathrm{p}}$ & 2.3 & $>2.2$ & $>2.5$ & $>2.5$ & 2.8 & $>2.5$ & 2.2 \\
\hline$\xi_{\mathrm{eq}}$ & 0.19 & 0.12 & 0.13 & 0.17 & 0.17 & 1 & 1 \\
\hline Failure mode & Beam failure & Beam failure & Beam failure & Beam failure & Column failure & Column failure & Column failure \\
\hline
\end{tabular}

Note: The "/" represents the number can not be calculated according to the measured data.

\section{Conclusions}

This paper investigates the seismic behavior of biaxial hollow RC slab to CFST column connections, where seven specimens were tested. Based on this study, the following conclusions may be drawn:

1) The proposed composite slim floor system inherently meets the principle of strong joint-weak member, indicating that there is no need to check the shear resistance of joint

2) For specimens with beam failure, the failures are mainly caused by the fracture of top steel beam flange. For specimens with column failure, the failures are primarily triggered by the buckling of tube wall.

3 ) To avoid the bond failure of rebars, a good anchorage should be suggested for the rebars at exterior joints in practical rational designs.

4) The ultimate story drift is 2.2-2.8 times of plastic drift ratio specified in codes and the equivalent damping coefficient for all specimens at peak loads ranges from 0.12 to 0.19 . (d) Energy dissipation

The equivalent damping coefficient $\xi_{\text {eq }}$ is adopted to represent the energy dissipation ability of specimens, which is defined as

$$
\xi_{\mathrm{eq}}=\left(S_{\mathrm{ABC}}+S_{\mathrm{ADC}}\right) /\left[2 \pi\left(S_{\mathrm{OBE}}+S_{\mathrm{ODF}}\right)\right]
$$

where $S_{\mathrm{ABC}}$ is the area enclosed by the curve $\mathrm{ABC}$ shown in Fig. 17. Definitions for $S_{\mathrm{ADC}}, S_{\mathrm{OBE}}$, and $S_{\mathrm{ODF}}$ are similar. The $\xi_{\mathrm{eq}}$ values for all specimens at peak loads are given in Table 3, which range from 0.12 to 0.19 . Since the average $\xi_{\mathrm{eq}}$ is about 0.1 for normal RC joints, the energy dissipation ability of the proposed joints is slightly better than conventional RC joints.

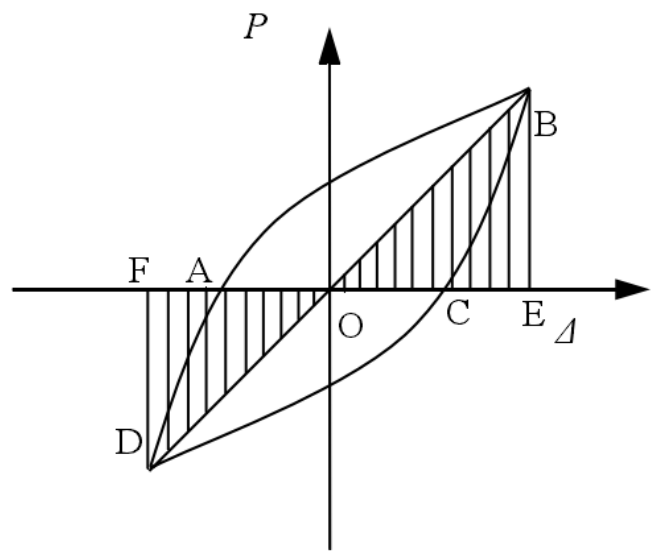

Fig. 17 The calculation of equivalent damping coefficient

\section{Nomenclature}

$A_{\mathrm{c}}$

$A_{\mathrm{s}}$

$f_{\mathrm{cc}}$

$f_{\mathrm{u}}$

$f_{\mathrm{y}}$

$L$

$n$
$N$

$N$

$P$
$P_{\mathrm{u}}$

$P_{\mathrm{u}}$
$P_{\mathrm{y}}$

$P_{\mathrm{y}}$
$U$

$U_{\mathrm{u}}$

$U_{\mathrm{y}}$ the cross-sectional area of infilled concrete the cross-sectional area of steel tube the axial compressive strength of infilled concrete the ultimate strength of stee the yield strength of steel the length between composite beam pins the axial load ratio of CFST column the axial compressive load applied on CFST column the applied vertical load at beam end the vertical peak load the vertical yield load the vertical displacement at beam end the vertical ultimate displacement the vertical yield displacement the story drift 
$\theta_{\mathrm{p}} \quad$ the plastic story drift

$\theta_{\mathrm{u}} \quad$ the ultimate story drift

$\mu \quad$ the ductility factor

$\xi_{\mathrm{eq}} \quad$ the equivalent damping coefficient

\section{Acknowledgements}

The authors greatly appreciate the financial support provided by the National Key R\&D Program of China (No. 2016YFC0701201) and the National Natural Science Foundation of China (No. 51408620).

\section{References}

[1] Mullett D L. Slim floor design and construction[M]. UK: Steel Construction Institute, 1992

[2] Lawson R M, Mullett D L, Rackham J W. Design of asymmetric slimflor beams using deep composite decking[M]. Berkshire: Steel Construction Institute, 1997.

[3] Ryu J, Ju Y K, Yoon S W, Kim S D. Bending capacities of glass fibre reinforced plastic composite slab[J]. Materials Research Innovations, 2013,17(sup2): 12-18.

[4] Silvana, D N, Ana L H C. Composite connections in slim-floor system: An experimental study[J]. Journal of Constructional Steel Research, 2012, 68(1):78-88

[5] Bailey C G. The behaviour of asymmetric slim floor steel beams in fire[J]. Journal of
Constructional Steel Research, 1999, 50(3): 235-257

[6] Ma Z, Mäkeläinen P. Behavior of composite slim floor structures in fire[J]. Journal of Structural Engineering, 2000, 126(7): 830-837.

[7] $\mathrm{Lu} \mathrm{X} \mathrm{H}$, Makelainen P. Strength and stiffness of composite slim floor beams $[\mathrm{C}]$ Proceedings of the 4st Pacific structural steel conference, 1995

[8] Malaska M. Behaviour of a semi-continuous beam-column connection for composite slim floors[M]. Helsinki University of Technology, 2000.

[9] Bernuzzi C, Gadotti F, Zandonini R. Semi-continuity in slim floor steel-concrete composite systems[C]//1st European Conference on Steel Structures, Athens, Greece. 1995.

[10] De Nardin S, El Debs A L H C. Study of partially encased composite beams with innovative position of stud bolts[J]. Journal of Constructional Steel Research, 2009, 65(2): 342-350.

[11] Hosseinpour E, Baharom S, Badaruzzaman W H W, Al Zand A W. Push-out test on the we opening shear connector for a slim-floor steel beam: Experimental and analytical study[J]. Engineering Structures, 2018, 163: 137-152

[12] CECS 159: 2004.Technical specification for structures with concrete-filled rectangular steel tube members; 2004 [in Chinese].

[13] JGJ/T 101-2015. Specification for seismic test of buildings; 2015 [in Chinese].

[14] Park, R. "Ductility evaluation from laboratory and analytical testing." Proceedings of the 9th world conference on earthquake engineering, Tokyo-Kyoto, Japan, 1988.

[15] American Society of Civil Engineers. Minimum design loads for buildings and other structures. Virginia: ASCE/SEI 7-10; 2010.

[16] GB 500011-2010. Code for seismic design of buildings; 2010 [in Chinese]. 